\title{
Influence of implementation of major regional projects on the socio-ecological-economic system (using the example of the Republic of Tatarstan)
}

\author{
Anatoliy Makarov ${ }^{1, *}$, Artem Nagimov ${ }^{1}$, Elvira Abdullina ${ }^{1}$, Tatyana Mansurova ${ }^{1}$, and \\ Ekaterina Khovanskaya ${ }^{2}$ \\ ${ }^{1}$ Kazan Federal University (Naberezhnye Chelny Branch), Higher School of Economics and Law, \\ 423810, Naberezhnye Chelny, Russia \\ ${ }^{2}$ Kazan Federal University, Institute of International Relations, Pravo-Bulachnaya St, 55, Kazan, \\ Respublika Tatarstan, 420111, Russia
}

\begin{abstract}
The article is devoted to the new trends of sustainable development of the Republic of Tatarstan in conditions of implementation of the large regional projects. Classification of the most significant regional projects implemented in the Republic of Tatarstan in recent years is presented in the article. On the basis of these projects, new "growth points" of the development of the regional economy are formed. Macro-economic effects of projects' implementation caused by changes of the key indicators are observed. Activities of the regional authorities to ensure environmental safety aimed at reduction of the negative impact on the environment within the implementation of the large regional projects are described in the article.
\end{abstract}

\section{Introduction}

The earlier proclaimed policy of turning Russia into the raw empire demonstrated its dead-end character. Today the questions of innovative development have come to the fore. However, in our country, the number of regions with active, innovative activity is small because of the nature of economic policy, and innovation activities are manifested in different ways.

Modern Russian strategic objectives are connected with concentration of efforts to ensure the transition of the economy of regions from the resource to the neo-industrial type of development, which, in turn, actualizes the necessity of development and the scientific substantiation of the mechanism of the controlled transformation of the socio-economic system of the region based on completeness and integrity of the formation of economic and social spheres. Major regional projects which are the factor of the sustainable, steady and socially-oriented development of the territorial unit can be one of the main directions of state regulation of social and economic development of the region, encouraging the quality improvement of the regional economic space, the creation of conditions for the use of the

\footnotetext{
* Corresponding author: Makarovfksu@yandex.ru
} 
resource and intellectual potential of the territory. In this regard, the role of regions in development and implementation of their own economic line increases, and the opportunity to become more economically independent is provided to the regions, which is also characterized by the tendency towards autonomy of the regions and the expansion of possibilities to use their own resources in the development of the region, the country as a whole. Here we mean the development of international relations, attraction of investments, the formation of the brand in the area, the free use of its own resources, especially the established socio-economic, scientific-technical and other capabilities that provide the solution to many social and economic problems in the region taking into account the interests of the population. Efficient use of available resources of the region is a prerequisite for sustainable territorial development [1]. On the basis of these aspects, the region develops its own development strategy. Investments attracted to the area contribute to the creation of the conditions for the sustainable and qualitative development of the territory which includes social security, economic growth, development of resources and economic potential. Major regional projects are a tool for their implementation. In our opinion, "major regional project" is a project that is significant for the region, that contributes to changes in the social, ecological and economic system and that is focused, after all, on the improvement of the quality of life.

\section{Implementation of the large regional projects in the republic of Tatarstan}

In recent years, a lot of the large regional projects that had a significant impact on the socioecological-economic system of the region, have been implemented in the Republic of Tatarstan. A list of the most prestigious major regional projects implemented (and planned) in the Republic of Tatarstan, is shown in Table 1.

Table 1. The most significant major regional projects in the Republic of Tatarstan.

\begin{tabular}{|l|l|c|c|}
\hline \multicolumn{1}{|c|}{ Project } & Type of project & $\begin{array}{c}\text { Pnvestment } \\
\text { final results }\end{array}$ \\
\hline $\begin{array}{l}\text { Complex of refineries and } \\
\text { petrochemical plants of the } \\
\text { joint stock company } \\
\text { "TANEKO" } \\
\text { (Nizhnekamsk) }\end{array}$ & $\begin{array}{l}\text { Industrial production } \\
\text { project }\end{array}$ & 130.3 bln. rubles & $7-8$ years \\
\hline $\begin{array}{l}\text { Complex of residues } \\
\text { reduction of the refinery } \\
\text { plant of the joint stock } \\
\text { company "TAIF-NK" } \\
\text { (Nizhnekamsk) }\end{array}$ & $\begin{array}{l}\text { Industrial production } \\
\text { project }\end{array}$ & 58.46 bln. rubles & \\
\hline $\begin{array}{l}\text { Development of the } \\
\text { integrated complex of the } \\
\text { production of ammonia, } \\
\text { methanol and granulated } \\
\text { carbamide in Mendeleevsk }\end{array}$ & $\begin{array}{l}\text { Industrial production } \\
\text { project }\end{array}$ & 48 bln. rubles & \\
\hline $\begin{array}{l}\text { Republican special-purpose } \\
\text { program "Development of } \\
\text { housing construction in the } \\
\text { Republic of Tatarstan in } \\
\text { 2011-2015." }\end{array}$ & $\begin{array}{l}\text { Program of support } \\
\text { and development of } \\
\text { housing and business }\end{array}$ & 451 bln. rubles & $6-7$ years \\
& & $\begin{array}{l}\text { Formation of } \\
\text { agglomerations of the } \\
\text { major cities of the RT, } \\
\text { system development of } \\
\text { the territory, incentive of } \\
\text { the elaboration of the base } \\
\text { industry of construction } \\
\text { products }\end{array}$ \\
\hline
\end{tabular}




\begin{tabular}{|c|c|c|c|}
\hline $\begin{array}{l}\text { Construction of the turnpike } \\
\text { "Shali-Bavly." }\end{array}$ & $\begin{array}{l}\text { Project of engineering } \\
\text { and transport } \\
\text { infrastructure }\end{array}$ & 132 bln. rubles & 30 years \\
\hline $\begin{array}{l}\text { Anniversary celebration } \\
\text { "Millennium of Kazan." }\end{array}$ & $\begin{array}{l}\text { Program } \\
\text { development of the } \\
\text { territory }\end{array}$ & 140 bln. rubles & $\begin{array}{l}\text { More than } 200 \text { major } \\
\text { facilities were put into } \\
\text { operation; development of } \\
\text { transport infrastructure in } \\
\text { Kazan }\end{array}$ \\
\hline $\begin{array}{l}\text { Program of development of } \\
\text { the Federal State } \\
\text { Autonomous Educational } \\
\text { Institution of Higher } \\
\text { Professional Education } \\
\text { "Kazan (Volga Region) } \\
\text { Federal University" for } \\
2010-2019\end{array}$ & $\begin{array}{l}\text { Project of creation of } \\
\text { the educational center } \\
\text { in the region }\end{array}$ & 11.375 bln. rubles & $\begin{array}{l}\text { Creation of the new } \\
\text { integrated University, } \\
\text { assistance to solve the } \\
\text { issues of socio-economic } \\
\text { development of the } \\
\text { Republic of Tatarstan and } \\
\text { the Volga Region Federal } \\
\text { District }\end{array}$ \\
\hline $\begin{array}{l}\text { Playground of the World } \\
\text { Cup in } 2018\end{array}$ & $\begin{array}{l}\text { Project of rising the } \\
\text { sports importance and } \\
\text { development of } \\
\text { infrastructure in the } \\
\text { region }\end{array}$ & 30.275 bln. rubles & $\begin{array}{c}\text { Construction and } \\
\text { reconstruction of } \\
\text { infrastructural facilities, } \\
\text { development of the } \\
\text { territory }\end{array}$ \\
\hline University Games 2017 & $\begin{array}{l}\text { Project of rising the } \\
\text { sports importance and } \\
\text { development of } \\
\text { infrastructure in the } \\
\text { region }\end{array}$ & 228 bln. rubles & $\begin{array}{l}\text { Construction and } \\
\text { reconstruction of } \\
\text { infrastructural facilities, } \\
\text { development of the } \\
\text { territory }\end{array}$ \\
\hline $\begin{array}{l}\text { Program of development of } \\
\text { tourism of Spassky } \\
\text { municipal district and the } \\
\text { city of Bolgar for } 2011-2016\end{array}$ & $\begin{array}{l}\text { Program } \\
\text { development of the } \\
\text { territory }\end{array}$ & 4.6 bln. rubles & $\begin{array}{c}\text { Sustainable development } \\
\text { of Spassky municipal } \\
\text { district and the city of } \\
\text { Bolgar }\end{array}$ \\
\hline $\begin{array}{l}\text { Development of } \\
\text { (Special Economic } \\
\text { "Alabuga" }\end{array}$ & $\begin{array}{l}\text { Industrial production } \\
\text { project, development } \\
\text { of infrastructure in the } \\
\text { region; creation of } \\
\text { conditions for the } \\
\text { development r of } \\
\text { Russian and } \\
\text { international } \\
\text { companies }\end{array}$ & 105 bln. rubles & $\begin{array}{c}\text { Construction of } \\
\text { infrastructural facilities }\end{array}$ \\
\hline $\begin{array}{l}\text { Development of } \\
\text { (Special Economic } \\
\text { "Innopolis." }\end{array}$ & $\begin{array}{l}\text { Program } \\
\text { development of the } \\
\text { territory and } \\
\text { development of } \\
\text { innovation potential } \\
\text { of the region and the } \\
\text { country }\end{array}$ & 120 bln. rubles & $\begin{array}{c}\text { Foundation of a new city, } \\
\text { development of } \\
\text { innovative products in the } \\
\text { sphere of information } \\
\text { technologies }\end{array}$ \\
\hline
\end{tabular}

The above-mentioned information says about the sustained priority strategic focus of the regional authorities on the implementation of the large regional projects. The Republic of Tatarstan, in comparison with many entities of the Russian Federation, was less effected by the world economic crisis of 2008-2009 and the slowdown in the economy to a lesser extent. The combination of the diversified economy, export-resource industries, developed service sector in the major cities, support for the innovation potential and the improvement of the investment climate are largely the reasons of this. Major regional projects that are not aimed at the here-and-now profit are ascertainment of the latter [2].

In 2014, the Russian Federation was in a difficult economic situation connected with the deficit budget in conditions of crisis. However, in the frames of the major regional projects in Kazan and in the other parts of the republic the engineering, transport, sports and other infrastructure facilities were not idle, out of action, they were effectively used. It should be noted that in the Republic of Tatarstan petroleum refining, petrochemical industry, 
automotive cluster, etc. were the traditional key "growth points." The projects that have been recently completed show that these industries do not lack attention from the regional authorities and investors and that they continue to develop their capacity. But at the same time, the new "growth points" indicated in such areas as the innovation sector, research institutions, the sphere of tourism, are identified in the republic. The accounting of key "growth points" allows planning the amount of necessary investments in capital assets at different stages of the economic cycle of infrastructure development in the region.

\section{Analysis of trends in the sustainable development of the area}

In the recommendations of the OECD, sustainable development is considered from the position of quantitative and qualitative changes [3], it is shown in the dynamic evolution of the economy, manufacturing, and other industries, spheres and areas of economic activity, the quality of life of the population. Implementation of the projects caused a macroeconomic effect in the republic, which is expressed as a change of the set of social, economic and environmental performance indicators. We present the generated partial indices of the composite index of the region and the index data for the Republic of Tatarstan (see Table 2, Table 3).

Table 2. Partial indices of the composite index of stability of Republic of Tatarstan (increment of growth to the previous year).

\begin{tabular}{|l|c|c|c|c|c|c|c|}
\hline \multicolumn{1}{|c|}{ Indicator } & $\begin{array}{c}\text { Sign of } \\
\text { the } \\
\text { indicato } \\
\text { r in } \\
\text { CSC }\end{array}$ & $\mathbf{2 0 1 2}$ & $\mathbf{2 0 1 3}$ & $\mathbf{2 0 1 4}$ & $\mathbf{2 0 1 5}$ & $\mathbf{2 0 1 6}$ & $\mathbf{2 0 1 7}$ \\
\hline Volume index of GRP & + & 8.31 & -3.67 & 4.64 & 6.15 & 5.94 & 2.59 \\
\hline $\begin{array}{l}\text { Volume index of } \\
\text { investment in fixed assets }\end{array}$ & + & 6.09 & -3.56 & 14.68 & 8.42 & 9.39 & 5.94 \\
\hline $\begin{array}{l}\text { Index of the degree of } \\
\text { depreciation of fixed } \\
\text { assets }\end{array}$ & - & 2.89 & -1.24 & -3.68 & 5.23 & -3.49 & 0.72 \\
\hline Index of unemployment & - & 13.25 & -77.86 & 27.43 & 26.91 & 13.52 & 2.57 \\
\hline $\begin{array}{l}\text { Index of average monthly } \\
\text { gross nominal wages and } \\
\text { salaries of employees of } \\
\text { organizations }\end{array}$ & + & 31.75 & 2.15 & 14.93 & 16.23 & 17.07 & 12.77 \\
\hline $\begin{array}{l}\text { index of average } \\
\text { consumer spending per } \\
\text { capita }\end{array}$ & - & -33.49 & -8.15 & -16.26 & -17.97 & -18.82 & -10.54 \\
\hline $\begin{array}{l}\text { Index of population size } \\
\text { with income below the } \\
\text { subsistence minimum }\end{array}$ & - & 1.2 & 3.68 & 7.65 & -5.5 & 20.93 & -11.4 \\
\hline $\begin{array}{l}\text { Volume index of } \\
\text { innovative goods, works } \\
\text { and services }\end{array}$ & + & -30.85 & 22.4 & -13.73 & -4.79 & 25.12 & 15.69 \\
\hline
\end{tabular}




\begin{tabular}{|l|c|c|c|c|c|c|c|}
\hline $\begin{array}{l}\text { Index of housing area per } \\
\text { inhabitant (on average) }\end{array}$ & + & 0.24 & 1.45 & 3.38 & 2.32 & 1.81 & 1.09 \\
\hline $\begin{array}{l}\text { Index of the number of } \\
\text { registered crimes }\end{array}$ & - & 0.77 & 13.98 & 17.97 & 6.41 & 7.63 & 11.82 \\
\hline $\begin{array}{l}\text { Index of the number of } \\
\text { people engaged in } \\
\text { physical culture }\end{array}$ & + & 8.36 & 8.36 & 13.44 & 15.59 & 9.59 & 26.76 \\
\hline $\begin{array}{l}\text { Index of morbidity of } \\
\text { population }\end{array}$ & - & 2.48 & -6.09 & 2.36 & -0.44 & 0.57 & 1.71 \\
\hline $\begin{array}{l}\text { Index of emissions of } \\
\text { pollutants into the air } \\
\text { from stationary sources }\end{array}$ & - & -3.12 & 2.26 & 1.93 & -5.92 & -3.73 & -3.6 \\
$\begin{array}{l}\text { Index of wastewater } \\
\text { discharge into surface } \\
\text { water bodies }\end{array}$ & - & 3.36 & 8.27 & -12.07 & -1.69 & 2.52 & 2.8 \\
\hline $\begin{array}{l}\text { Volume index of recycled } \\
\text { and consequently used } \\
\text { water }\end{array}$ & + & 3.64 & -2.51 & 2.26 & 2.29 & -8.04 & -8.58 \\
\hline $\begin{array}{l}\text { Index of forest } \\
\text { reproduction }\end{array}$ & + & 11.55 & -44.2 & -18.08 & 21.89 & 0 & 4.51 \\
\hline
\end{tabular}

Table 3. Data on the composite index of stability of the Republic of Tatarstan, 2008-2017.

\begin{tabular}{|c|c|}
\hline Year & Composite index of stability \\
\hline 2012 & 1.65 \\
\hline 2013 & -5.29 \\
\hline 2014 & 2.92 \\
\hline 2015 & 4.69 \\
\hline 2016 & 5.01 \\
\hline 2017 & 3.68 \\
\hline
\end{tabular}

According to Tables 2 and 3, it is possible to describe the features that determine the trend of development of the region. In 2010-2012, the indicators of socio-economic development of the Republic of Tatarstan showed the improvement of the economic situation. A lot of performance indicators analyzed by us in the economic bloc had a positive dynamics. In 2011 , the growth rate of the gross regional product of the Republic of Tatarstan was 105,7\% compared to 2010. Significant loss of the gross regional product in 2009 - due to the global financial crisis - was replaced and had the growth in the subsequent years. After the period of economic growth (2010-2012), in 2017, there were the trends of deceleration in the Republic of Tatarstan. External demand for regional products declined as far as external factors, including the negative situation in the world market, as well as adverse weather conditions, which led to the loss of the crop and caused the rise of food prices, had a significant impact on it. The effect of the high base of 2012 in the other sectors of the economy led to a slowdown of the gross regional product in 2017 to $102,4 \%$ compared to the level of 2012 (in 2012 - 105,5\%). GRP growth rates exceeded the growth rates of GDP of the Russian Federation. According to experts, in 2017, the GRP was 1,52 trillion rubles.

It is necessary to note the contribution and the annual production growth in the innovative infrastructure of the Republic, which is supported by the special economic zones, technology parks, IT-parks. At 2012 year-end, its residents output $47 \mathrm{bln}$. rubles of production. The volume of innovative products, services tended to decrease over the past few years, but since 2012 the parity was restored, and the republic has a positive value. Nevertheless, it is 
necessary to give a more applied nature to innovative technologies. The calculated partial indices for 2008, 2010 and 2011 are $-30,85,-13,73$ and $-4,79$ respectively. There is a paradoxical situation in the light of the fact that innovative activity is one of the priorities of the development of the Republic. Innovative infrastructure is expanded and modernized; the investment is involved in the innovation sector. In addition, innovations are a buzz word and sound familiar, the innovations are vigorously debated in the Government of the Republic of Tatarstan and "picked up" by the media.

The macroeconomic situation is characterized by moderate growth in the region and in the country. This situation is typical for the performance indicators of the social standard of living and quality of life. For example, in 2017, the average nominal monthly wage of company employees was 26035 rubles. The Republic of Tatarstan is still in the first place in the Volga Federal District, but in the Russian Federation, it is only in the middle of the table. It should be noted that consumer expenditures per capita in the region are growing as well, and the growth is above the average monthly nominal wage of employees of organizations, in 2017 it was 21013 rubles, the republic is also in the first place among the regions of the Volga Federal District and on the 9th place in the Russian Federation. The number of people with income below the minimum subsistence is $7,2 \%$. During four years the housing area per capita on the average has been steadily growing. Undoubtedly, the Republican specialpurpose program "Development of housing construction in the Republic of Tatarstan in 20112015 " contributes to it. In general, the indicator in the Republic reflects the similar situation in Russia. In 2017, it was 24,2 m2. In 2012-2017, the total volume of construction in the Republic of Tatarstan also increased to $10,68 \%$ and $4,89 \%$, respectively.

The index of the unemployed, as well as the other macroeconomic indicators, has been particularly significant on the agenda in 2009. During the global financial crisis, the number of unemployed of the region has grown almost 2 times, and in the republic, the unemployment rate was $8,4 \%$. A set of measures aimed at unemployment reduction produced the effect. In 2017, the unemployment rate was 4\%. Unfortunately, in the book "Regions of Russia" there is no information concerning the number of people who go in for sports. In the open access, the statistics regarding the number of individuals who go in for sports is available only on the website of the Ministry of Sports of the Russian Federation. Analysis of the index number of people who go in for sports showed that every year the percentage of the population who go in for sports has been steadily growing, for the last 4 years this index has increased in average by $10 \%$. Of course, the "sports boom" in the republic, especially in its capital, has a favorable effect on the spiritual, educational process of personality development, public health becomes better.

The negative situation is in the ecological system of the republic. The analyzed indicators, such as air emissions, discharge of polluted waste water, reforestation tend to deterioration. In terms of discharge of polluted waste water into surface water bodies and of the reforestation, the Republic of Tatarstan is one of the outsiders in the Volga Region Federal District. These analyses reflect the deterioration of the ecological situation in the region, the ignorance of which cannot lead to sustainable development of the area. In addition, there is no a steady downward trend in the population morbidity rate. On the contrary, in 2009 there was a sharp negative increase, in 2011, there was an increase in comparison with 2010 . We think that deterioration of indices of the ecological system and of morbidity rate are the consequences of one and the same logical chain that allow us to speak about the factors that hamper the sustainable development of the region. 


\section{Ecological safety of the area in conditions of implementation of the large regional projects}

In 2017, the financing of environmental programs and activities in the Republic of Tatarstan was included in the funds of the federal, republican and municipal budgets. Within the implementation of the Program of social and economic development of the Republic of Tatarstan for 2011-2015 approved by the Law of the Republic of Tatarstan from 22.04.2011 \#13-ZRT, in 2017 the work to develop the funds of 3 popular programs in the field of environmental protection was carried out:

- the popular special-purpose program "Development of the water resources complex of the Republic of Tatarstan for 2017-2020", approved by the Cabinet of Ministers of the Republic of Tatarstan from 29.09.2012 \# 804;

- the popular special-purpose program "Environmental Security of the Republic of Tatarstan for 2017-2015", approved by the Cabinet of Ministers of the Republic of Tatarstan from 31.10.2012 \# 934;

- long-term special-purpose program "Environmental protection of Nizhnekamsk and Nizhnekamsk Municipal District", approved by the Cabinet of Ministers of the Republic of Tatarstan from 16.03.2012 \# 222.

Targeted expenditure of the sovereign budgetary funds to finance environmental protection measures was provided by the RT Law "Budget of the Republic of Tatarstan for 2017 and for the planning period of 2014 and 2015". In the republican budget 819,8 million rubles were allocated for the implementation of special-purpose programs. Special-purpose financing of environmental activities of the RT was carried out by the main areas of environmental activities (environmental protection, reforestation, construction and reconstruction of engineering protection facilities, restoration and environmental rehabilitation of water facilities, protection of atmospheric air, etc..).

Ecological safety of the region was one of the critical components of a successful implementation of the Universiade project. On behalf of the First Deputy Prime Minister of the Russian Federation I.I. Shuvalov the draft concept of environmental protection was developed to perform this task. Within this conception, the cost financial-economic certification in the amount of about 2 billion rubles for implementation of the activities was prepared by the following areas:

I. Integrated assessment and environmental forecasting;

II. Water-resources conservation;

III. Waste utilization system;

IV. Landscaping and site are finishing.

Implementation of the measures was carried out using the budgetary and extra-budgetary funds of all levels: federal, republican and municipal budgets of Kazan. A number of steps to expand the network of environmental pollution monitoring at the expense of the federal budget were executed with the support of Ministry of Natural Resources of Russia. Improved efficiency of supply of relevant information of the environmental condition in the city was due to the introduction of two automated stations of air pollution monitoring into the surveillance network of Roshydromet (Federal Service for Hydrometeorology and Environmental Monitoring) and technical modernization of the integrated laboratory. Considerable financial expenses of the federal budget were allocated to a number of activities of bank protection of significant water bodies of the city involved in the competitions of the Universiade - Kazanka river and the lake Sredny Kaban. Using the funds of the republican budget the works to develop the system of summary calculations of atmospheric air pollution for the city of Kazan are carried out stepwise to ensure the required atmospheric air quality. A number of activities of the Concept concerning landscaping and site finishing of the city 
and in the waste utilization system were carried out under the coordination of the Executive Committee of Kazan.

In preparation for the Universiade - together with the implementation of the activities of the Concept - particular attention is paid to the state environmental supervision as a tool to detect and to prevent violations in the field of environmental protection, and the inspectors from the environmental authorities are mobilized. Ministry of Ecology and Natural Resources of the Republic of Tatarstan organized the system of surveillance for violations of air protection legislation in order to implement appropriate supervisory measures. Establishment of the facts of violations of environmental law, including by the results of operation of unmanned aerial vehicles, is carried out. The decision to suspend operations before for the modernization of the production process is made based on the results of the supervisory activities in regard to a number of the city enterprises that significantly pollute the atmospheric air and that don't meet the requirements of the environmental protection legislation. Work with the JSC "NefisKosmetiks", a large enterprise located in the city center that stopped - as a result of the modernization processes - emissions of specific substances with an unpleasant odor into the atmosphere, is one of the examples.

Unprecedented large-scale actions of city gardening which were actively supported by the inhabitants of Kazan (the action "Green Record", "100 parks") were held in order to improve the environmental well-being of the capital. In addition, the municipality speeded up the construction of clean-up systems of storm sewage treatment and started the implementation of the separate waste collection. New comfortable recreation and sports areas with well-developed embankment appeared in Kazan thanks to the complex interaction of public authorities and the scientific community. Within the concept of environmental protection during the preparation and implementation of the large regional projects the implemented measures were intended to provide environmental security, to improve the environmental condition and the welfare of the urban environment, to minimize environmental damage. But the analysis of the key environmental indicators in recent years and environmental condition in the republic shows that it is necessary not only to reduce but to increase the financing of the environmental sphere, at the same time it is a need to develop and implement major environmental projects aimed at quality improvement of the environment in the region.

The sharp increase in budget funding for environmental measures in 2017 is primarily due to the allocation of funds resources for minimization of environmental damage and reduction of the negative impact on the environment due to the implementation of the large regional projects in the republic. The principles of sustainable development should be taken into account already in the project development.

\section{Ecological safety of the area in conditions of implementation of the large regional projects}

Sustainable development of the region, high living and health standard of the population can be provided only in conditions of preservation of the ecosystem and maintenance of the appropriate quality of the environment. Sustainable development of the regional economy is impossible without reduction of the existing social inequality and environmental destruction. The transformation of this understanding into some practical steps to solve this problem and the transition to sustainable forms of development and rational way of living is the main objective of the near future. It is necessary to develop and to implement - step by step - the socio-ecological-economic policy aimed at improvement of the quality of life, environmental protection and rational use of resources in order to solve this problem. 
Implementation of the large regional projects affects the performance indicators of the composite index. Thus, it is possible to plan and simulate the situation after the implementation of projects. In the context of sustainable development, it is feasible to implement those necessary projects that will contribute to its maintenance. At the same time, it is a need to say that these activities require the involvement of a variety of human, time and other resources for effective management decisions.

\section{References}

1. Towards Sustainable Development: Indicators to Measure Progress. Rome Conference (OECD, 1998)

2. A.R. Nagimov, E.V. Nagimova, European Science and Technology, 7th International scientific conference 1, 290-293 (2014)

3. A.A. Ajupov, O.E. Medvedeva, A.V. Sarkin, International Business Management 10(24), 5752-5756 (2016)

4. K.H. Olsen, Energy Policy 36, 2819-2830 (2008)

5. A.A. Artamonova, A.A. Ajupov, Mediterranean Journal of Social Sciences 6(1S3), 2429 (2015)

6. A.A. Ajupov, A.A. Kurilova, R.S. Ozernov, Asian Social Science 11(11), 23-29 (2015)

7. A.A. Ajupov, A.A. Kurilova, D.U. Ivanov, Asian Social Science 11(11), 1-6 (2015)

8. A.A. Ajupov, A.A. Kurilova, K.Y. Kurilov, V.D. Bogatirev, Asian Social Science 11(11), 168-175 (2015)

9. A.A. Artamonova, A.A. Ajupov, Mediterranean Journal of Social Sciences 6(1S3), 2429 (2015)

10. A.A. Ajupov, T.V. Polteva, Life Science Journal 1(6), 464-468 (2014)

11. A.A. Ajupov, O.E. Medvedeva, A.V. Freze, A.G. Savin, A.S. Karataev, Journal of Engineering and Applied Sciences 12(19), 4894-4898 (2017)

12. O.E. Medvedeva, III International Research-to-Practice Conference "Modern Information Technologies and Innovations in Economy, State and Municipal Management and Social Sciences" (MITEC - 2018) Proceedings 1-1 (2018) 